\title{
UNIT KEGIATAN BELAJAR MANDIRI JITU PEMBELAJARAN DARING BERMUTU DI MASA PANDEMI
}

\author{
I KETUT SUARDINATA \\ SMAN 1 Negeri Jember \\ Email: iketutsuardinata4@gmail.com
}

\begin{abstract}
ABSTRAK
Sistem Kredit Semester (SKS) adalah bentuk penyelenggaraan pendidikan yang peserta didiknyamenyepakati jumlah beban belajar yang diikuti dan/atau strategi belajar setiap semester pada satuan pendidikan sesuai dengan bakat, minat, dan kemampuan/kecepatan belajarnya. Penyelenggaraan Sistem Kredit Semester di SMA merupakan upaya pemerintah untuk menjawab amanat Undang-Undang bahwa setiap peserta didik adalah individu yang unik, sehingga harus dilayani proses belajarnya dengan cara yang berbeda-beda sesuai dengan potensi dan kebutuhan belajar peserta didik yang beragam. Keberagaman adalah sebuah keniscayaan dalam suatu komunitas belajar di dalam kelas, dan setiap pribadi peserta didik memiliki hak untuk mendapatkan layanan pendidikan sesuai dengan keunikannya. Dengan demikian, pendampingan dan pembimbingan oleh guru terhadap setiap peserta didik menjadi bersifat heterogen sesuai dengan heterogenitas mereka sebagai pribadi-pribadi yang unik dengan kelebihan dan kekurangannya masing-masing. Dalam pola layanan seperti itu dibutuhkan alat bantu berupa bahan belajar yang disebut Unit Kegiatan Belajar Mandiri (UKBM) dan Buku Teks Pelajaran (BTP). UKBM merupakan satuan pelajaran kecil yang dijabarkan lebih operasional dari Rencana Pelaksanaan Pembelajaran (RPP) yang sudah disusun terlebih dahulu. UKBM memuat Kompetensi Inti (KI) dan Kompetensi Dasar (KD) serta strategi pembelajaran individual untuk mencapai ketuntasan beban belajar yang telah ditentukan terkait penguasaan peserta didik terhadap pengetahuan dan keterampilan serta memberikan dampak pengiring terbangunnya karakter yang dibutuhkan dalam kehidupan abad 21. Dari hasil UKBM dalam kegiatan belajar mengajar meningkatkan efektivitas siswa dalam belajar karena meningkatnya nilai siswa di bidang Biologi.
\end{abstract}

Kata Kunci : Metode Pembelajaran, Kegiatan Belajar Mandiri, Sekolah Menengah Atas.

\section{PENDAHULUAN}

Pandemi Covid-19 yang muncul di Indonesia sejak awal bulan Maret 2020 telah mengubah pola kegiatan belajar di sekolah. Kegiatan belajar mengajar yang telah terprogram di awal semester mau tidak mau di tengah jalan harus disesuaikan dengan kondisi tidak normal yang melanda. Kebijakan Dinas Pendidikan Provinsi Jawa Timur menindaklanjuti Surat Edaran Gubernur Jawa Timur menetapkan bahwa kegiatan pembelajaran dilaksanakan dengan memanfaatkan teknologi informasi dan komunikasi dalam bentuk kegiatan Belajar dari Rumah (BDR) dan guru-guru melaksanakan tugas Mengajar dari Rumah secara online. Instruksi tersebut dilaksanakan untuk mendukung social distancing/physical distancing sesuai protokol kesehatan dari pemerintah pusat. Adanya kebijakan pelaksanaan proses pembelajaran sebagaimana tersebut di atas memaksa guru mengubah bentuk dan cara-cara pembimbingan dan pendampingan siswa-siswinya. Guru-guru harus menyiapkan rencana kegiatan pembelajaran secara khusus dan melaksanakannya secara khusus pula dengan memanfaatkan berbagai fasilitas teknologi komunikasi yang tersedia. Berbagai fasilitas teknologi informasi dan komunikasi yang dapat dimanfaatkan di antaranya adalah WhatsApp, Google Drive, Google Form, Google Classroom dan sebagainya. Semua hal tersebut dilakukan dengan tetap mempertimbangkan penjaminan tercapainya Kompetensi Dasar (KD) kurikulum. Proses belajar mengajar menjadi sangat berbeda, dan guru-guru maupun siswa mau tidak mau harus beradaptasi dengan situasi dan kondisi yang ada. Tanpa terpikirkan sebelumnya, pandemi Covid-19 telah mengajarkan kepada guru-guru untuk selalu siap berubah dan berkreasi dalam menjalankan tugas profesi. 
Pasca pandemi covid 19 masuk ke Indonesia dengan jumlah yang terdampak positif penderita covid 19 semakin bertambah, maka kemudian pertengahan Maret 2020 untuk menekan angka penderita covid 19, pemerintah provinsi dan pemerintah daerah menghasilkan kebijakan dalam dunia pendidikan yaitu meniadakan sementara pembelajaran tatap muka diganti dengan pembelajaran online (Fey dalam CNN Indonesia, 2020). Menurut Oktafia, dkk (2020) dalam jurnal nya menyebutkan kebijakan dari pemerintah yang mengatur hal tersebut ialah Surat Edaran Kementerian Pendidikan dan Kebudayaan (Kemendikbud) Direktorat Pendidikan Tinggi No. 1 Tahun 2020 mengenai pencegahan penyebaran covid 19 di dunia Pendidikan. Dalam surat edaran tersebut Kemendikbud menginstruksikan untuk menyelenggarakan pembelajaran jarak jauh dan menyarankan para peserta didik untuk belajar dari rumah masing-masing. Penyediaan materi kuliah yang dilakukan secara online serta materi tersebut dapat diakses oleh siapapun yang membutuhkan dapat menjadi salah satu pelayanan pendidikan lain yang dapat diakses melalui sarana internet.

Guru yang baik selalu berpikir tentang kualitas pembelajaran yang dilakukan terhadap peserta didiknya dalam kondisi apapun. Kualitas pembelajaran dapat dilihat dari bentukbentuk atau cara mendampingi danmembimbing siswa dalam aktivitas belajarnya baik secara individual maupun dalam kelompok-kelompok, dan dapat pula dilihat dari prestasi hasil belajar yang berhasil dicapai oleh peserta didik. Kualitas pembelajaran bukanlah sebuah kebetulan, tidak terjadi sekonyong-konyong, melainkan berakar dari sebuah perencanaan, kerja keras dan komitmen (Asrori : 2008). Pembelajaran yang berkualitas tidak bersifat baku, statis, dan kaku melainkan bersifat dinamis, fleksibel, dan berkembang dalam rangka menjawab kebutuhan serta tantangan jaman yang selalu berubah. Pembelajaran berkualitas harus didisain dan direncanakan dengan baik. Merencanakan kegiatan pembelajaran tertuang dalam Rencana Pelaksanaan Pembelajaran (RPP) yang menggambarkan aktivitas guru dan para siswa tahap demi tahap hingga mencapai kompetensi yang diharapkan. Di sekolah penyelenggara Sistem Kredit Semester (SKS), Rencana Pelaksanaan Pembelajaran dijabarkan lebih operasional ke dalam bahan belajar yang disebut Unit Kegiatan Belajar Mandiri (UKBM) atau Unit Kegiatan Belajar Mandiri dalam format digital (e-UKBM). Unit Kegiatan Belajar Mandiri pada intinya merupakan model bahan belajar (learning material) yang menuntut peserta didik untuk belajar lebih mandiri dan aktif. UKBM/e-UKBM juga penting dan diperlukan untuk membantu memudahkan guru di dalam mendampingi dan membimbing peserta didik yang sangat beragam dalam melaksanakan kegiatan belajarnya. Dengan menggunakan UKBM dimungkinkan pula terselenggaranya kegiatan belajar mengajar tanpa kehadiran guru secara fisik, namun tetap dapat mengontrol/mengendalikan aktivitas belajar peserta didik sesuai tuntutan standar proses.

Ketersediaan bahan belajar berupa UKBM menjadi sangat penting di masa pandemi Covid-19. Dengan menggunakan UKBM, keharusan melaksanakan kegiatan belajar dan mengajar dari rumah menjadi cukup mudah dan praktis menuju kepada pencapaian Kompetensi Dasar (KD) yang telah ditetapkan di kurikulum satuan pendidikan. Guru juga dapat dengan cukup mudah mengembangkan aktivitas-aktivitas belajar tambahan berbasis UKBM untuk meningkatkan kompetensi peserta didik. Kegiatan belajar juga menjadi semakin mudah, interaktif, menarik dan menyenangkan dengan dukungan teknologi informasi yang ada dalam kehidupan modern sekarang ini. Berdasarkan kesadaran, pemahaman dan pemikiran seperti itulah muncul di benak penulis untuk mengembangkan kegiatan belajar dengan strategi, metode, dan pendekatan khusus di saat kondisi tidak normal akibat pandemi. Setidaknya ada dua hal yang dapat penulis jadikan sebagai topik pembelajaran penting dan menarik terkait pandemi Covid-19 bagi para peserta didik, yaitu pemahaman tentang sistem kekebalan tubuh (imunitas), dan pengembangan sikap ilmiah. Kedua topik tersebut merupakan bagian dari struktur materi pelajaran Biologi di kelas X dan XI SMA. Maka dari itulah sebagai pendidik, penulis melaksanakan kegiatan belajar dari rumah dengan cara mengoptimalkan fungsi Unit Kegiatan Belajar Mandiri (UKBM) dan memberi tugas tambahan secara khusus. 
Kegiatan belajar mengajar sebagai satu kesatuan proses yang utuh menuju pada pencapaian kompetensi tertentu dapat ditingkatkan mutu prosesnya maupun hasilnya melalui pengembangan aktivitas belajar yang bersifat memperluas dan memperdalam. Memperluas dan memperdalam aktivitas belajar dilakukan dengan memberi tugas tambahan. Tugas tambahan diberikan dalam konteks pandemi Covid-19 dengan tujuan melatih siswa menghasilkan karya ilmiah, berlatih mengeksplorasi berita dan fakta-fakta, dan logika berpikir peserta didik sebagai bagian dari masyarakat ilmiah meskipun pada taraf yang masih sangat sederhana. Tugas menyusun karya tulis ilmiah berupa Kajian Ilmiah singkat tentang pandemi Covid-19 juga diharapkan meningkatkan pemahaman siswa tentang sistem imun dalam tubuh manusia serta dapat menstimulasi tumbuhnya kesadaran peserta didik untuk tampil sebagai pelopor dan panutan bagi masyarakat awan dalam menyikapi suatu musibah dalam kehidupan. Komunikasi dan interaksi antara guru dan peserta didik dan antar peserta didik, mudah dilakukan dengan ketersediaan media internet dan berbagai aplikasi media Teknologi Informasi (TI). Melalui cara tersebut di atas, penulis berupaya untuk selalu memikirkan dan melaksanakan hal terbaik dan berkualitas bagi para siswa dalam berprestasi, bahkan di masa sulit penuh kendala sekalipun.

\section{METODE PENELITIAN}

Metode penelitian yang digunakan secara khusus berkaitan dengan pembelajaran pada mata pelajaran Biologi, sebagai guru yang nota bene seorang professional, penulis berpikir dan melakukan beberapa langkah persiapan untuk merencanakan aktifitas pembelajaran yang bersifat khusus. Penulis menemukan dan menetapkan bahwa ketersediaan Unit Kegiatan Belajar Mandiri (UKBM/e-UKBM) sebagai bahan belajar dalam kegiatan Belajar dari Rumah menjadi sangat penting dan cukup memudahkan.

Langkah-langkah Kegiatan yang penulis lakukan sebagai berikut:

1. Persiapan:

1) Menyusun RPP khusus (modifikasi) untuk kegiatan Belajar dari Rumah.

2) Menyiapkan UKBM/e-UKBM dan BTP sesuai program semester.

3) Menyusun instrument penilaian formatif menggunakan LMS (Learning Management System)

2. Melaksanakan Kegiatan Belajar dan Mengajar dari Rumah sesuai jadwal khusus.

3. Melaksanakan Penilaian Formatif.

4. Melaksanakan Kegiatan Remidi dan Pengayaan.

\section{HASIL DAN PEMBAHASAN}

Prosedur dan mekanisme aktivitas Belajar dari Rumah menggunakan UKBM/e-UKBM menunjukkan bahwa fungsi dan peran UKBM/e-UKBM sangat penting dan menjadi salah satu alternative solusi yang tepat untuk mengatasi kesulitan akibat pandemi. Lebih dari itu, penggunaan UKBM/e-UKBM dapat menyediakan ruang yang lebih terbuka bagi keterlibatan dan peran orang tua dalam mengawal, mendampingi dan membimbing belajar putra-putrinya di rumah. Para orang tua siswa bahkan tanpa sadar menjadi lebih tahu bagaimana putraputrinya dalam belajar, mengerjakan tugas-tugas, melakukan eksplorasi informasi pengetahuan dari Buku Teks Pelajaran (BTP) dan berbagai sumber belajar lainnya serta memberi bantuan bilamana diperlukan. Kondisi tersebut sudah tentu memberi nilai tambah terhadap proses belajar yang dilakukan siswa bila ditinjau dari hakikat proses pendidikan bagi peserta didik yang juga menjadi tanggung jawab orang tua. Guru dan orang tua siswa dapat membangun komunikasi yang lebih intensif, bahkan kolaboratif dalam mengawal aktivitas belajar siswa selama masa belajar dari rumah. Bentuk aktivitas belajar yang demikian akan lebih menjamin terjadinya proses belajar bermakna (Ausubel, 1977).

Secara keseluruhan, aktivitas para siswa terekam dalam berbagai dokumen proses dan hasil pembelajaran sebagai berikut:

1. Kumpulan tugas-tugas siswa 
Berbagai aktivitas belajar yang dilakukan oleh siswa dideskripsikan di dalam UKBM/eUKBM, berupa tuntunan atau perintah untuk dikerjakan oleh siswa, yang kemudian diikuti oleh pertanyaan-pertanyaan yang harus dijawab, semuanya dilaporkan oleh siswa melalui proses upload melalui link Google Drive yang disiapkan oleh guru.

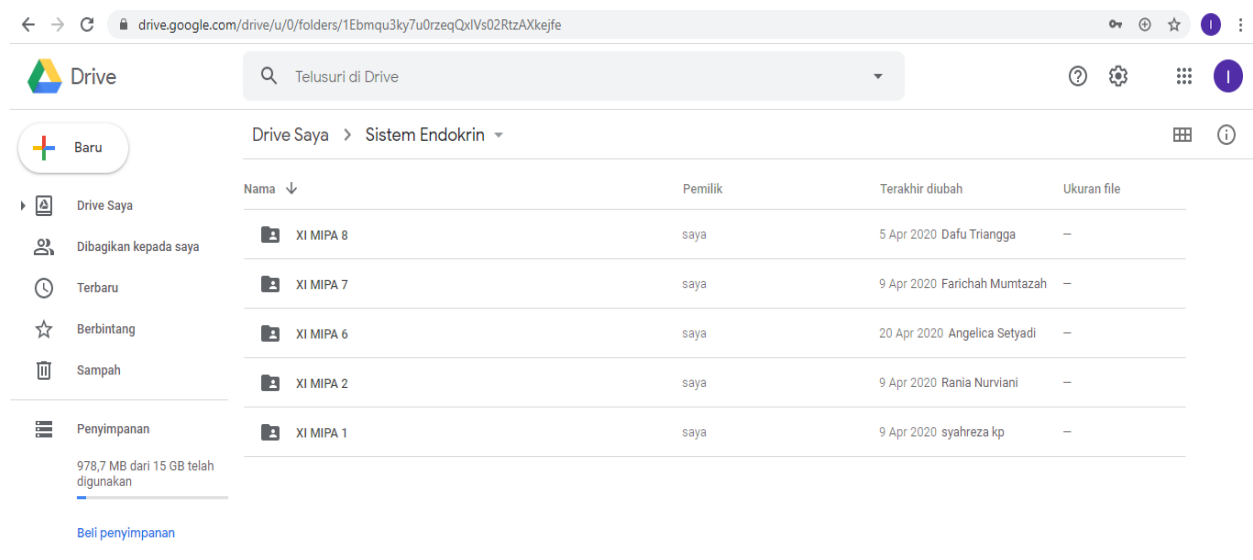

Gambar 1. Daftar Penyerahan Tugas UKBM Bio-3.10/4.10/2/10

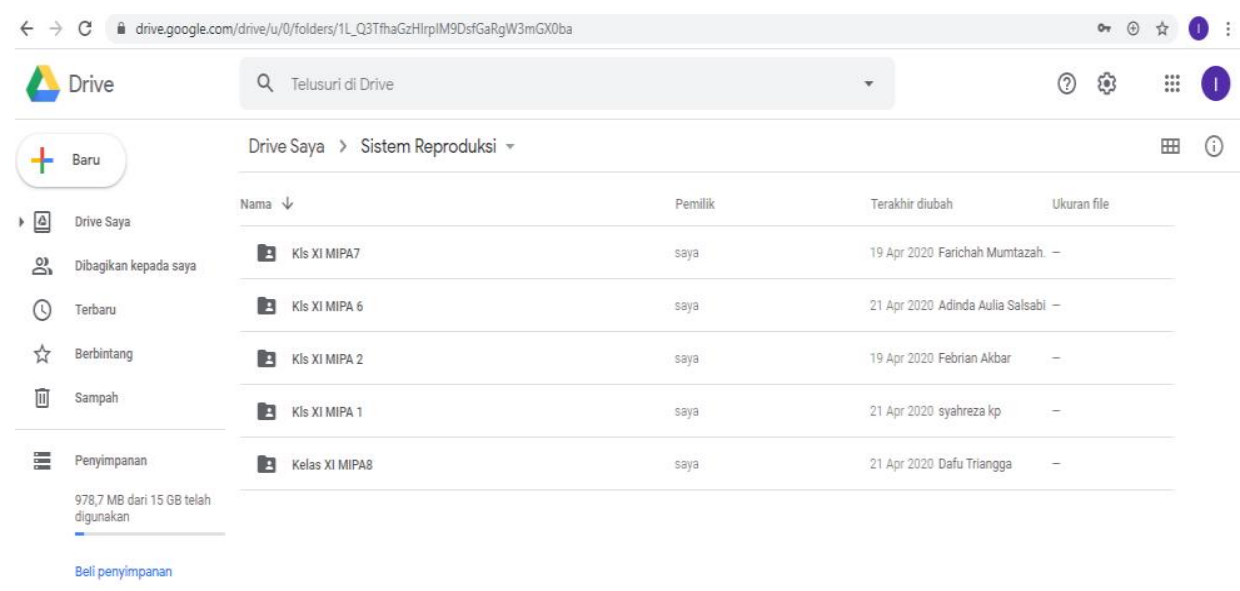

Gambar 2. Daftar Penyerahan Tugas UKBM Bio-3.12/4.12/2/12

2. Hasil Penilaian Formatif

Sejak kegiatan Belajar dari Rumah dilaksanakan mulai pertengahan bulan Maret 2020, beberapa kali dilaksanakan penilaian formatif sesuai program semester (Promes) yang telah disusun di awal semester.

3. Analisis Daya Serap terhadap Materi Pelajaran

Analisis daya serap terhadap materi pelajaran dilakukan melalui analisis hasil tes formatif untuk mengetahui daya serap dan tingkat ketuntasan belajar peserta didik pada Kompetensi Dasar (KD) tertentu. Di samping itu, analisis juga dilakukan dalam rangka untuk mengetahui konsep-konsep yang belum dipahami dengan baik sehingga perlu dilaksanakan program remedial.

4. Kegiatan Remidi dan Pengayaan

Kegiatan remidi dilakukan dengan memberi tugas kepada siswa untuk mengulang kembali kegiatan belajar pada UKBM/e-UKBM dan diskusi/tanya jawab melalui WhatsApp group kelas (WAG kelas), atau melalui WhatsApp jalur pribadi, dilaksanakan di luar jadwal pelajaran. Setelah selesai, diakhiri dengan tes remedial. Dari 5 (lima) kelas/rombel, yaitu kls XI MIPA 1, XI MIPA 2, XI MIPA 6, XI MIPA 7, dan XI MIPA 8, dengan jumlah siswa secara keseluruhan 156 orang, sebanyak 23 orang harus menempuh program remedial. Remedial diberikan dengan meminta siswa untuk membaca kembali UKBM/e-UKBM dan BTP dengan lebih cermat. Kegiatan remedial diakhiri dengan melaksanakan tes ulang (tes 
remidi). Siswa/siswi yang tidak lulus tes remidi dan yang tidak menempuh tes karena alasan tertentu, diberi tugas secara khusus dengan tetap berpijak pada prinsip-prinsip penilaian.

5. Kumpulan Karya Tulis Ilmiah

Karya tulis ilmiah siswa berupa hasil kajian terhadap fenomena pandemi Covid-19 dimaksudkan selain untuk meningkatkan pemahaman siswa tentang sistem imun, juga untuk menstimulasi peserta didik agar mulai tumbuh dan terbangun sikap ilmiah sebagai bekal untuk melanjutkan pendidikan pada jenjang yang lebih tinggi. Tugas membuat kajian ilmiah pandemi Covid-19 disesuaikan dengan tingkat kemampuan analisis dan bernalar para siswa. Di tingkat Sekolah Menengah Atas (SMA), peserta didik sudah memiliki pengalaman dasar menulis karya ilmiah sederhana antara lain berupa laporan hasil praktikum pada mata pelajaran Fisika, Kimia, dan Biologi, menyusun paper maupun makalah untuk dipresentasikan di kelas dan lain-lain. Pengalaman tersebut penting untuk terus ditumbuhkembangkan dan diasah secara berkelanjutan. Secara kebetulan, adanya pandemi Covid-19 cukup tepat dan sangat relevan untuk tujuan tersebut, ditambah lagi, substansi kajian sangat berkaitan erat dengan konsep-konsep dalam mata pelajaran Biologi yang harus dikuasai oleh siswa seperti, agen penginfeksi (virus, bakteri, jamur dan sebagainya), proses penularan penyakit, dan sistem pertahanan tubuh (imunitas) pada manusia.

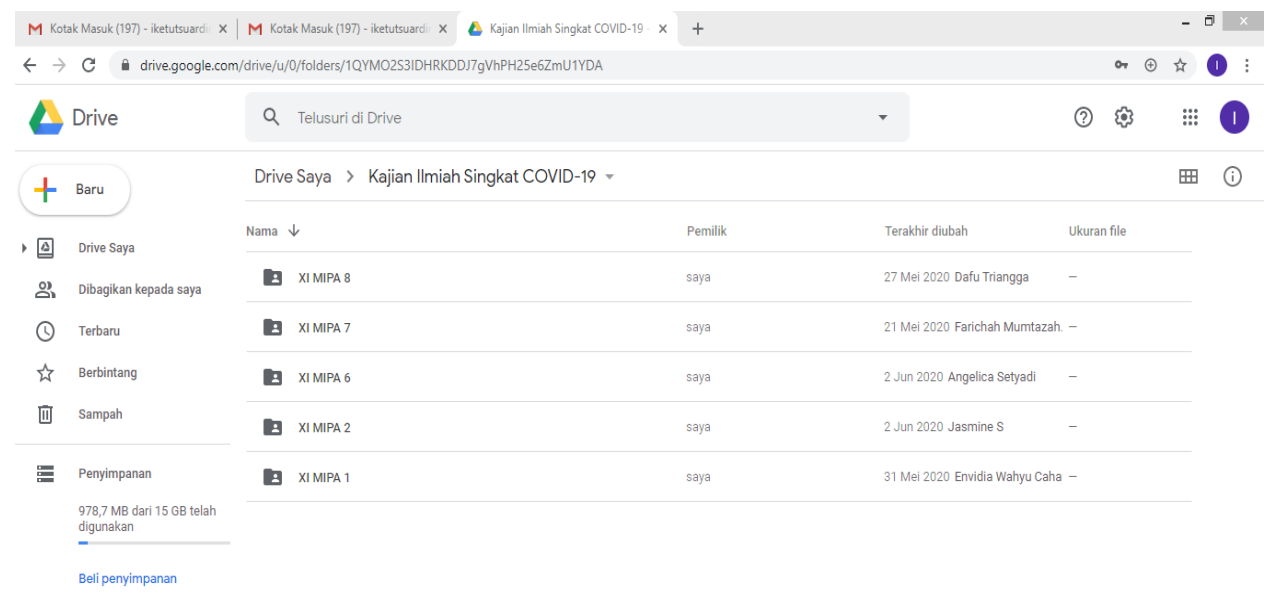

Tabel 4. Daftar Penyerahan Tugas Kajian Ilmiah

\section{Refleksi}

Sejak awal pelaksanaan kegiatan Belajar dari Rumah (BDR) berbagai kendala teknis muncul dan situasi ketidakberdayaan dalam mengelola pembelajaran yang baik dan kondusif menjadi sebuah tantangan untuk dihadapi dan dicarikan solusi. Berbagai hambatan, kendala/kesulitan dan permasalahan tak terelakkan di antaranya:

1) Pengurangan alokasi waktu belajar dari 4 Jam Pelajaran menjadi 2 Jam Pelajaran per minggu, berakibat pada keterbatasan kesempatan untuk mendiskusikan materi esensial yang sulit dan belum dikuasai dengan baik oleh peserta didik. Lebih dari itu, dengan keterbatasan waktu yang ada, pelaksanaan tes formatif juga memerlukan pengaturan waktu yang tidak mudah. Beberapa kali tes formatif dengan terpaksa dilaksanakan pada malam hari.

2) Beberapa Kegiatan Belajar (KB) dalam UKBM/e-UKBM tidak dapat dilaksanakan oleh peserta didik sesuai prosedur yang semestinya, terutama kegiatan yang mengharuskan siswa berinteraksi dengan lingkungan fisik maupun sosial, karena terbentur oleh ketentuan-ketentuan dalam protokol kesehatan yang harus dipatuhi. Hal ini berakibat pada tidak terakomodasinya kebutuhan pengalaman belajar dan penilaian pada aspek keterampilan (psikomotor) dan sikap (afektif).

3) Guru mengalami kesulitan dan tidak dapat melakukan pengontrolan terhadap aktivitas belajar siswa sebagaimana seharusnya, dengan kata lain guru tidak dapat 
mengawal bagaimana siswa belajar di rumah. Hal ini juga berakibat pada munculnya kendala yaitu guru tidak dapat melakukan penilaian pada aspek sikap (afektif).

4) Guru kesulitan mengukur dan menilai kesiapan belajar para siswa karena tidak mengetahui kondisi fisik dan mental peserta didik secara langsung. Hal itu berakibat pada munculnya berbagai kendala bagi guru karena tidak dapat menerapkan strategi pembelajaran yang dinamis untuk menghantarkan peserta didik menuju pencapaian tujuan pembelajaran. Kesiapan secara fisik dan mental peserta didik dalam melaksanakan aktivitas belajar adalah syarat mutlak untuk pencapaian hasil belajar secara optimal (Asrori, 2008).

5) Kerap terjadi, melalui telpon atau pesan WhatsApp beberapa orang tua siswa bahkan mengeluhkan keadaan putra-putrinya yang harus mengerjakan tugas-tugas yang cukup banyak, karena hampir semua mata pelajaran mengembangkan cara Belajar dari Rumah dengan memberi tugas. Kondisi ini juga menjadi bahan untuk dipertimbangkan secara bijaksana oleh penulis, sehingga pemberian tugas dirancang/disiapkan sedemikian rupa agar tidak terlalu membebani siswa.

Di sisi lain, berbagai hal baru yang memberi harapan sekaligus tantangan dalam meningkatkan mutu pembelajaran ke depannya dapat diperoleh. Harapan dan tantangan tersebut di antaranya:

1) Unit Kegiatan Belajar Mandiri khususnya dalam format digital (e-UKBM) tampak cukup layak dipertimbangkan menjadi pilihan bahan belajar yang ideal untuk mendampingi peserta didik belajar secara mandiri. Di samping itu e-UKBM juga mampu menjawab tuntutan kebutuhan dan perkembangan jaman khususnya tuntutan di era teknologi informasi dan komunikasi seperti sekarang ini dan masa yang akan datang.

2) e-UKBM sebagai dokumen digital memiliki fleksibilitas tinggi, adaptif dan terbuka sehingga dalam penggunaannya selalu dapat di-update dengan cepat dan mudah baik substansi maupun teknis/variasi aktivitas belajar yang dilakukan peserta didik sesuai tuntutan kondisi yang selalu berubah dan berkembang.

3) Penggunaan e-UKBM akan semakin efisien dan efektif ditunjang oleh fasilitas teknologi informasi yang semakin berkembang dan canggih

\section{KESIMPULAN}

Kegiatan Belajar dari Rumah pada mata pelajaran Biologi kelas XI yang telah dilaksanakan oleh peserta didik di masa pandemi Covid-19 sejak tanggal 16 Maret 2020 yang lalu hingga akhir semester genap Tahun Pelajaran 2019/2020 di SMA Negeri 1 Jember, menunjukkan hasil sebagai berikut:

1. Melalui upaya mengoptimalkan penggunaan bahan belajar berupa Unit Kegiatan Belajar Mandiri (UKBM/e-UKBM) pada materi Sistem Koordinasi, Bahaya Penyalahgunaan NAPZA, Sistem Reproduksi dan Sistem Imun, dan didukung fasilitas teknologi informasi dan komunikasi yang tersedia, para siswa tetap memperoleh pengalaman belajar yang bermakna dan mampu menunjukkan hasil belajar yang membanggakan meskipun kondisi sangat tidak normal.

2. Pemberian tugas menyusun kajian ilmiah singkat tentang pandemi Covid-19 sangat relevan diberikan untuk meningkatkan pemahaman siswa pada materi sistem Imun (sistem pertahanan/kekebalan tubuh manusia).

3. Pemberian tugas menyusun kajian ilmiah singkat tentang pandemi Covid-19 dapat mendorong siswa untuk berlatih menuangkan kemampuan analisis data dan fakta-fakta, logika, dan kreatifitas berpikir dalam bentuk karya tulis ilmiah.

\section{DAFTAR PUSTAKA}

Asrori, M. (2017). Psikologi Pembelajaran. Bandung: CV Wacana Prima 
Fey. CNNIndonesia. (n.d.-b). 65 Kampus Kuliah Dari Rumah, Sultan Yogya Ragukan Efektivitas. Retrieved from https://www.cnnindonesia.com/nasional/2020031611070720-483756/65- kampus-kuliah-dari-rumah-sultan-yogya-ragukan-efektivitas. diakses pada Juni 2020.

Herliandry, L. D., Nurhasanah, N., Suban, M. E., \& Kuswanto, H. (2020). Pembelajaran pada masa pandemi COVID-19. Jurnal Teknologi Pendidikan, 22(1), 65-70. https://doi.org/10.21009/jtp.v22i1.15286

Irnanintyas. (2014). Biologi untuk SMA/MA Kelas XI. Jakarta: Penerbit Erlangga

Kemdikbud. 2017. Modul Pengembangan Keprofesian Berkelanjutan: Biologi SMA. Jakarta: Kementerian Pendidikan dan Kebudayaan

Oktafia Ika Handarini., Siti Sri Wulandari. (2020). Pembelajaran Daring Sebagai Upaya Study From Home (SFH) Selama Pandemi Covid 19. Jurnal Pendidikan Administrasi Perkantoran (JPAP). Vol 8. No 3. Tahun 2020.

Prasasti, G. D. (2020). UNESCO: Penutupan sekolah akibat COVID-19 berdampak pada 290 juta pelajar di dunia. Diunggah dari https://www.liputan6.com/health/ read/4195275/unesco-penutupan-sekolahakibat-covid-19-berdampak-pada-290- jutapelajar-di-dunia pada 20 November 2020

Sugiyono. (2012). Metode Penelitian Kuantitatif Kualitatif dan R\&D. Alfabeta.

https://www.bulelengkab.go.id/detail/artikel/guru-sebagai-profesi-56. Diakses tanggal 10 Mei 2020 .

https://www.file.upi.edu/direktori/FPBS/JUR_PEND._BHS._SASTRA_INDONESIA/198001 292005011_ANDIKA_DUTHA_BACHARI/GURU_SEBAGAI_PROFESI_pdf. Diakses tanggal 10 Mei 2020. 